\title{
Oder Nehri Havzası'nda Yaşayanları Tehdit Eden Beşeri ve Doğal Faktörler
}

\author{
Hüseyin ŞAHBAZ1
}

\section{Özet}

Çalışmada araştırma sahası olarak Orta Avrupa'nın önemli akarsularından birisi olan Oder Nehri'nin havza alanı seçilmiștir. Oder Nehri, Vistül'den sonra Polonya'nın en uzun ikinci akarsuyudur. $118.861 \mathrm{~km}^{2}$ lik bir drenaj alanına sahip olan Oder; Polonya, Çekya ve Almanya'nın paylaștığı sınırașan bir nehir havzasıdır. Aynı zamanda Oder Nehri, inșa edilen kanallar aracılığıyla büyük sanayi ve ticaret bölgeleri arasındaki ulaşımı sağlayan önemli bir suyoludur. $\mathrm{Bu}$ araştırmanın amacı, Oder Nehri Havzası'nda yaşayanları tehdit eden beşeri ve doğal faktörlerin neler olduğunu belirlemektir. Araştırma kapsamında literatür taraması yapılarak konuyla ilgili veriler temin edilmiştir. Metin analizi yöntemiyle gözden geçirilen bu verilerden şu sonuçlara ulaşılmıştır: Tarım arazilerini ve kırsal yerleşmeleri sel ve taşkınlardan korumak amacıyla bu nehrin kolları üzerinde acil depolama yapıları inşa edilmiştir. Ancak bu yapıların hacimleri, büyük sellerle gelen suları depolayacak kapasitede değildir. Bu yüzden meydana gelen büyük sellerde nehrin yukarısındaki rezervuarlardan büyük miktarlarda su bırakılmakta ve bu da ekonomik kayıplara sebep olmaktadır. Ayrıca yoğun sanayileşmiş bölgelerden ve maden sahalarından geçmesi nedeniyle Oder'in suları, ağır metal kirliliğinin de tehdidi altındadır. Havzada yaşanan ve gelecekte daha da etkili olması beklenen bir diğer sorun da, küresel ısınmadır. Nitekim iklim değişikliğine bağlı olarak havzada kuraklığın gittikçe artması ve sıcaklık artışına bağlı olarak Oder'in haliç bölgesindeki su kalitesinde birtakım değişimlerin olması beklenmektedir. Bunlardan başka Polonya ve Almanya arasındaki tarihsel süreç, Oder Havzası sakinlerini tehdit etme potansiyeline sahip bir başka konudur. Nitekim geçmişte yaşanan iki dünya savaşından yenik çıkan Almanya, bu harplerde asırlardır aralarında ihtilafa konu olan ve Oder Havzası'nı da içine alan toprakları, Polonya'ya bırakmak zorunda kalmıştır.

Anahtar Kelimeler: Orta Avrupa, Oder Nehri Havzası, Sınıraşan Nehir Havzası, Uluslararası Nehir

\section{Human and Natural Factors Threatening Those Living in the Oder River Basin}

\begin{abstract}
In the study, the basin area of Oder River, one of the important streams of Central Europe, was chosen as the research area. Oder River is the second longest stream of Poland after Vistula. Oder has a drainage area of $118.861 \mathrm{~km}^{2}$; It is a transboundary river basin shared by Poland, Czechia

${ }^{1}$ Dr. Coğrafya Öğretmeni, Milli Eğitim Müdürlüğü, Afyonkarahisar

İlgili yazar e-posta/ Corresponding author e-mail: huseyiniyesuh@gmail.com ORCID No: 0000-0002-4808-0746

Bu makaleye atıf yapmak için- To cite this article Şahbaz, H. (2020). Oder Nehri Havzası'nda Yaşayanları Tehdit Eden Beșeri ve Doğal Faktörler. Afet ve Risk Dergisi,
\end{abstract} $3(1), 56-69$. 
and Germany. At the same time, the Oder River is an important waterway that provides transportation between major industrial and commercial areas through built canals. The purpose of this research is to determine the human and natural factors that threaten the inhabitants of the Oder River Basin. Within the scope of the research, the literature was scanned and data on the subject were obtained. From these data reviewed by the text analysis method, the following conclusions were reached: Emergency storage structures were built on the tributaries of this river to protect agricultural land and rural settlements from floods. However, the volumes of these structures are not capable of storing water coming from large floods. Therefore, in large floods, large amounts of water are released from the reservoirs upstream of the river, causing economic losses. In addition, Oder's water, which passes through densely industrialized areas and mining sites, is threatened by heavy metal pollution. Another problem in the basin that is expected to be more effective in the future is global warming. Indeed, due to climate change, it is expected that drought will increase in the basin and there will be some changes in the water quality in the Oder estuary due to the increase in temperature. Furthermore, the historical process between Poland and Germany is another issue that has the potential to threaten the inhabitants of the Oder Basin. As a matter of fact, Germany, which was defeated in both world wars, had to leave the lands that included the Oder Basin, which was the subject of conflict in these wars for centuries, to Poland.

Keywords: Central Europe, Oder River Basin, Transboundary River Basin, International River

\section{GíRIŞ}

$\mathrm{Su}$, her canlının hayatını sürdürmesi için gereken doğal kaynakların başında yer almaktadır. Diğer tüm doğal kaynaklardan farklı olarak su, yaşamın ana kaynağını oluşturmaktadır. İnsanlık tarihi boyunca medeniyetlerin kurulması, şekillenmesi ve gelişmesinde su, anahtar bir rol oynamıştır. Günümüzde de medeniyetini devam ettirmek için insanoğlu, suya muhtaçtır (Köle, 2017).

Aristo, Politika adlı eserinde kaleme aldığı "Devlet Teorisi” fikirleri arasında; doğal kaynakları kısıtlı olan bölgelerde devlet kurmanın zor olacağı, eğer kurulan varsa da bunların egemenlik sürelerinin uzun olmayacağı görüşünü ileri sürmüștür. Aslında bu tez, zenginlik kaynakları ile devletin gücü arasında sıkı bir paralellik bulunduğuna dikkat çekmesi açısından da önemlidir (Doğanay, 1997). Ülkelerin sahip olabileceği en önemli zenginlik kaynaklarından birisiyse hiç şüphesiz tatlı sulardır.

Dünya yüzeyinin dörtte üçü suyla kaplı olmasına rağmen, insan kullanımı için mevcut tatlı su miktarı çok sınırlıdır. Buna karşın sanitasyon, gıda üretimi, kentsel ve endüstriyel kullanım gibi neredeyse tüm insani faaliyetler için tatlı suya ihtiyaç vardır (Uitto, 2001). Dahası dünya nüfusunun artması, sanayinin gelișmesi, şehirleșmenin artması ve bunun bir sonucu olarak da artan atıklar, doğal kaynaklar üzerinde baskı yaratmaktadır. Özellikle karbon salımlarının artması ile dünya ikliminde önemli değişiklikler meydana gelmektedir. Yüzyılımızın en büyük çevre sorunu olarak nitelendirilen iklim değiş̧ikliği de, su kaynaklarını, canlı yaşamını tehdit edecek boyutta olumsuz etkilemektedir (Maden, 2013). Bütün bunların sonucu olarak da mevcudu sınırlı olan tatlı suya talep, her geçen gün artmakta ve bu da onu gittikçe daha da önemli bir meta kılmaktadır.

XX. yüzyılın ikinci yarısından başlayarak ve XXI. yüzyılın ilk on yılını kapsayan zaman diliminde su kaynakları ve su kaynaklarının yönetimine ilişkin olarak pek çok yeni kavram ortaya çıkmıştır (Bilen, 2008). Nitekim akarsuların sınıflandırılmasına ilișkin; ulusal sular, uluslararası sular ve sınıraşan sular olmak üzere geliştirilen üç temel kavram da bunlar arasındadır. 
Bunlardan ilki olan ulusal su kavramı; bir ülkenin resmi sınırları içinde kaynağını alıp yine aynı ülkenin resmi sınırları içerisindeki bir havzaya sularını deşarj eden yeryüzü sularını tanımlamakta kullanılır (Ilgar ve Salem, 2004). İkincisi olan sınıraşan su kavramı, bir ülkede doğduktan sonra başka bir ülkeye veya ülkelere geçen akarsuları tanımlamak için kullanılmaktadır (Baran vd., 2006). Uluslararası akarsu kavramını kullanmak içinse bir nehrin herhangi bir bölümünün seyredilebilir (yani ulaşıma elverişli) olması ve doğal olarak birden fazla devlete denize erişim sağlaması gerekmektedir (URL 1). Buna göre uluslararası bir akarsuyun aynı zamanda sınıraşan bir su olduğunu söylemek mümkünken, sınıraşan her suyun ise uluslararası bir akarsu olduğunu söylemek mümkün değildir.

Ulusal suların tamamı bir ülkenin kendi sınırları içinde kaldığından genel olarak bunlarla ilgili bir sorun yaşanmamaktadır. Ancak sınıraşan veya uluslararası sulardaysa bu suların üzerinde inşa edilen su yapılarına, kullanım miktarlarına, kirletilmesine ve ulaşım maksadıyla kullanılmasına bağlı olarak paydaş veya taraf ülkeler arasında birtakım anlaşmazlıklar yaşanabilmektedir.

Günümüzde iki veya daha fazla ülkenin sınırlarından geçen 263 tane akarsu havzası bulunmaktadır. Dünya nüfusunun \% 40'ının yaşadığı bu havzalar, küresel tatlı su akışının da yaklaşık \% 60'ını bünyesinde barındırmaktadır. Bundan başka uluslararası su yollarını paylaşan 145 devletten 21'i, aynı zamanda bir ya da daha fazla uluslararası havzanın hidrolojik sinırları içerisinde kalmaktadır (Giordano ve Wolf, 2003).

Sınıraşan sular açısından Avrupa Kıtası'na bakıldığında Tuna ve Ren gibi başlıca nehirlerden sonra bir diğer önemli akarsu olarak Oder'i anmak mümkündür (Şekil 1). Orta Avrupa'nın önemli Irmaklarından birisi olan Oder, Vistül'den sonra Polonya'nın en uzun ikinci akarsuyudur. 118.861 $\mathrm{km}^{2}$ lik bir drenaj alanına sahip olan (URL 2) Oder; Polonya, Çekya ve Almanya'nın paylaştığı sınıraşan bir nehir havzasıdır. Aynı zamanda Oder Nehri, inşa edilen kanallar aracılığıyla büyük sanayi ve ticaret bölgeleri arasındaki ulaşımı sağlayan önemli bir suyoludur.

Oder (ya da diğer adıyla Odra) Nehri, Çek Cumhuriyeti'nin doğusunda yer alan Hruby Jesenik Dağları'na düşen yağışlardan kaynağını almaktadır (Şekil 2). Buradan KD yönünde akışa geçen nehir, Ostrava kentini geçtikten sonra Çek Cumhuriyeti-Polonya sınırına gelmektedir. İki ülke sınırını 8,5 km çizdikten sonra yine Çekya-Polonya sınırını GD-KB istikameti boyunca çizerek akan, Olza kolunu almaktadır.

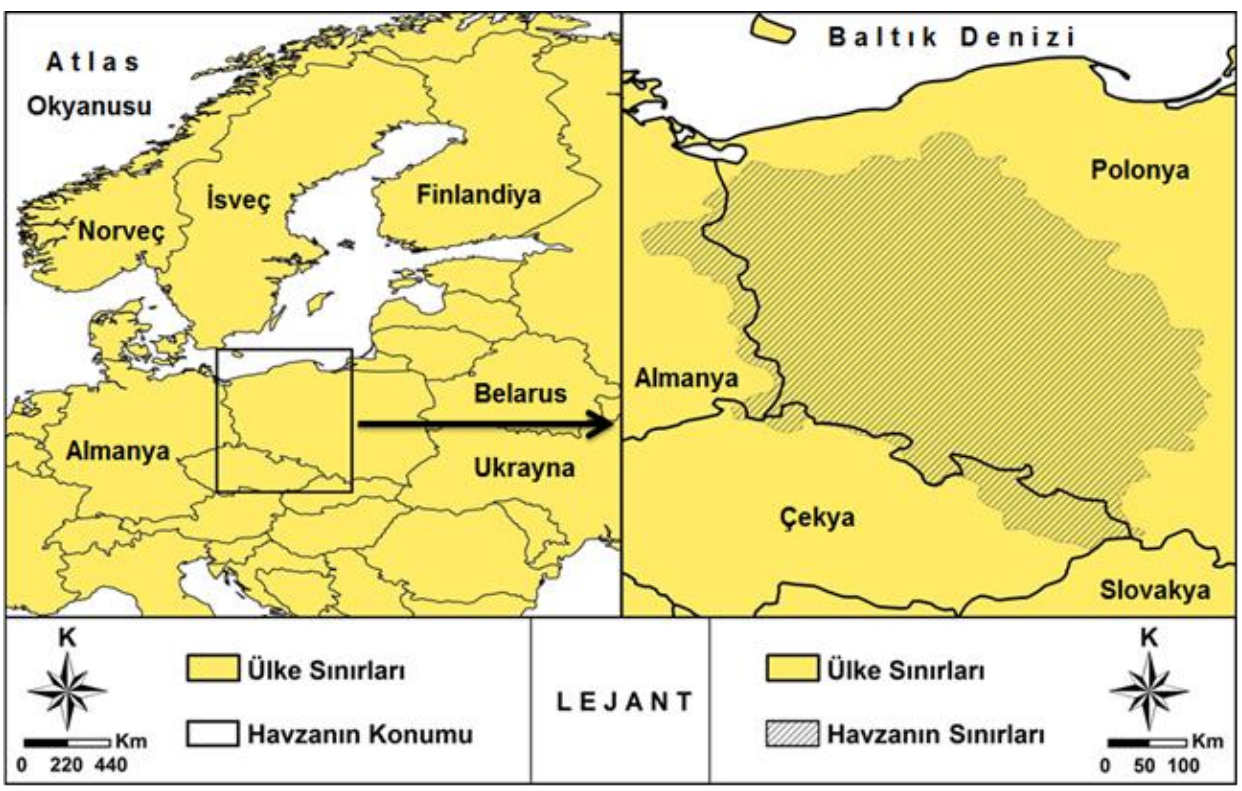

Şekil 1. Oder Nehri Havzası'nın Konumu ve Sınırları Haritası 


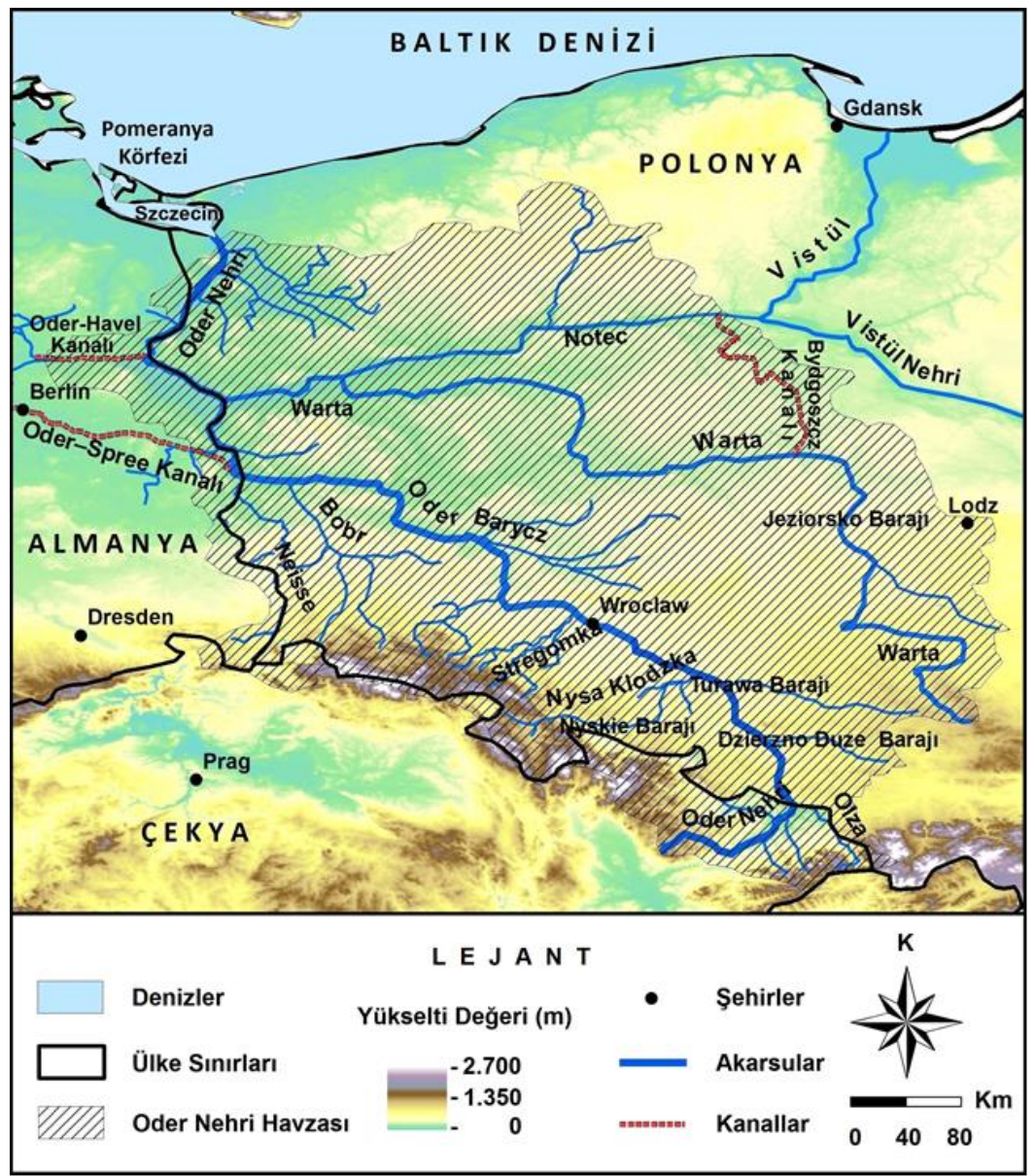

Şekil 2. Oder Nehri Havzası ve çevresinin fiziki haritası

Bundan sonra Polonya'nın güneyinden bu ülkeye geçen nehir, KB yönünde akmaya başlar. Raciborz, Opole, Wrocław șehirlerini geçerek ülkenin batı sınırına gelir. Buraya kadar Oder Nehri, Polonya toprakları boyunca $493 \mathrm{~km}$ yol almıștır. Burada Almanya-Polonya sınırını çizerek güneyden gelen Neisse (ya da Lusatian Neisse) koluyla birleşir. Buraya kadar genel olarak GD'den KB'ye doğru akan Oder, Neisse'yle birleşmesinden sonra kuzeye doğru yönelerek AlmanyaPolonya sınırını çizmeye başlar.

Sınır boyunca akışı sırasında Oder Nehri; Almanya'nın Brandenburg eyaletine bağlı Frankfurt şehrini geçtikten sonra Polonya'ya bağlı Kostrzyn şehrinde, doğu yönünden gelen ve aynı zamanda en uzun kolu olan, Warta'yı bünyesine almaktadır. Bundan sonra iki ülke sınırı boyunca önce KB, daha sonra da KD istikametinde akışına devam eden nehir, Polonya'ya bağlı Szczecin şehri yakınlarında iki kola ayrılarak tekrar bu ülkeye geçmektedir. Buraya kadar Oder, AlmanyaPolonya sınırını $180 \mathrm{~km}$ boyunca çizmektedir.

İkiye ayrılan kollardan Doğu Oder adını taşıyan sağdaki, Szczecin şehrinin doğusundan geçerek Dabie Gölü üzerinden Szczecin (veya Oder) Lagünü'ne akar. Batı Oder adı verilen sol kol ise bu göle hiç uğramadan Szczecin şehri içinden geçerek doğrudan Szczecin Lagünü'ne ulaşır. Nihayet Oder'in suları, bu lagün üzerinden 3 kol halinde Baltık Denizi'nde yer alan Pomeranya Körfezi'ne dökülmektedir.

Almanya-Polonya sınırını $180 \mathrm{~km}$ boyunca çizen Oder, sınırdan sonra Baltık Denizi'ne ulaşana kadar tekrar Polonya topraklarında 96 km daha akmaktadır. Böylece söz konusu nehir, Polonya'da 
toplam 589 km'lik bir yol kat etmektedir. Buna Çekya'da aktığı $115 \mathrm{~km}$ ve bu ülkeyle olan sınır boyunca aktığı 8,5 km de dâhil edildiği takdirde Oder Nehri'nin toplam 892,5 km'lik bir uzunluğa sahip olduğu anlaşılmaktadır. Buna göre Oder, Vistül'den sonra Polonya'nın en uzun ikinci nehridir.

Oder Nehri, $118.861 \mathrm{~km}^{2 \prime}$ lik bir akaçlama alanına sahiptir. Bu havza alanının \% 89,87'si sadece Polonya'ya aittir. Bundan başka \% 5,43 ile Çekya ve \% 4,7 ile de Almanya, havzayı paylaşan diğer ülkelerdir (Tablo 1).

Oder Nehri, sınırlı bir akışa sahiptir. Öyle ki, Baltık'a dökülen akarsular arasında en düşük akış hacmi, bu nehre aittir. Ayrıca akış hacmi, mevsimlere göre de değişmektedir. Nitekim yaz ve sonbahar boyunca düşük su periyodlarında akan nehre, bu dönemlerde üst kollarında yapılan rezervuarlardan sular bırakılmaktadır. Bununla birlikte dönem dönem atmosferik şartlara bağlı olarak yaz mevsiminde Oder Sistemi'nin aldığı aşırı yağışlar yüzünden nehirde seller meydana gelirken; bahardaysa eriyen kar ve buzullar nedeniyle akarsu, taşkınlara sebep olmaktadır (URL 3).

Tablo 1. Oder Nehir Havzası'nı paylaşan ülkeler (2009)

\begin{tabular}{|l|r|r|}
\hline Havza Ülkesi & Havza Ülkesindeki Yüzölçümü & (km \\
Polonya & 106.821 & Havza \%'si \\
\hline Çekya & 6.453 & 89,87 \\
\hline Almanya & 5.587 & 5,43 \\
\hline Toplam & $\mathbf{1 1 8 . 8 6 1}$ & 4,70 \\
\hline Kaynak: (URL 2) & & $\mathbf{1 0 0 , 0 0}$ \\
\hline
\end{tabular}

Gerçekten de havzanın büyük bir kısmını elinde bulunduran Polonya'da haziran ayından ağustos sonuna kadar etkili olan yaz koşullarında, sıcak ve kurak günler gibi ılık ve yağışlı günlere de rastlanmaktadır. Bu sebeple yaz mevsiminde hava, kışa oranla az nemli olmasına rağmen daha yağışlı geçmektedir. Özellikle temmuz, en sıcak ve yağışlı aydır (Akkan, 2007).

Oder Nehri'nin çok sayıda kolu bulunmaktadır. Bunlar içinde $54.480 \mathrm{~km}^{2 \prime}$ lik bir alanla havzanın yaklaşık yarısını oluşturan Warta, akaçlama alanı bakımından nehrin en büyük koludur. Ayrıca Warta, sahip olduğu 793,5 km akış mesafesiyle de yine Oder'in en uzun kolu durumundadır (KZGW, 2014). Buna göre her ne kadar bir nehrin kolu olsa da belirtilen akış mesafesiyle Warta; Vistül ve Oder'den sonra Polonya'nın en uzun üçüncü akarsuyudur.

Büyüklük açısından Oder'in ikinci büyük kolu, Barycz'dır. 133 km uzunluğa sahip olan bu nehrin $5.547,37 \mathrm{~km}^{2}$ 'lik bir akaçlama alanı bulunmaktadır. Barycz'i 2.150,6 km²'lik akaçlama alanı ve 129 km'lik uzunlukla Ina izlemektedir. Bundan başka büyüklük açısından sırayla; Mała Panew $\left(2.114,69 \mathrm{~km}^{2}\right.$ lik alan ve $132 \mathrm{~km}$ uzunlukla), Obrzyca $\left(1.804,98 \mathrm{~km}^{2}\right.$ lik alan ve $66 \mathrm{~km}$ uzunlukla), Widawa $\left(1745,9 \mathrm{~km}^{2}\right.$ lik alan ve $130,2 \mathrm{~km}$ uzunlukla), Stobrawa $\left(1.586 \mathrm{~km}^{2}\right.$ lik alan ve $78 \mathrm{~km}$ uzunlukla), Klodnica (1.003 km² lik alan ve $75 \mathrm{~km}$ uzunlukla) ve Krzycki Row (563 km² lik alan ve $72 \mathrm{~km}$ uzunlukla) nehrin diğer önemli kollarıdır (URL 4).

Oder Havzası'nda; Jeziorsko, Otmuchow, Nysa (Nyskie), Dzierzno Duze, Turawa,Bukowka, Pilchowice, Sosnowka, Mietkow, Slup, Lesna, Zlotniki, Topola ve Kozielno gibi çok sayıda baraj inşa edilmiştir (KZGW, 2014).

Adı geçen barajlardan en büyüğü, nehrin Warta kolu üzerinde yapılan, Jeziorsko'dur. Rezervuar kapasitesi 202,04 hm³ olan (URL 5) ve 1986 yılında tamamlanan bu baraj, çok amaçlı olarak inşa edilmekle birlikte ana yapılış nedeni, yağışlı dönemlerde meydana gelen taşkınları önlemektir. 
Bundan başka Büyük Polonya Voyvodalığı'ndaki şehirler için içme suyu sağlayan bu barajdan aynı zamanda kömürle çalışan Patnow-Konin ve Adamow termik santralleri için soğutma suyu temin edilmektedir. Ayrıca söz konusu barajdan hidroelektrik de üretilmektedir (Dysarz vd., 2006).

Havzanın ikinci büyük barajı, Nysa Klodzka Nehri üzerinde inşa edilen ve rezervuar kapasitesi $129,46 \mathrm{hm}^{3}$ olan, Otmuchow'dur. Bunu yine aynı kol üzerinde inşa edilen ve rezervuar kapasitesi $122,05 \mathrm{hm}^{3}$ olan Nyskie Barajı takip etmektedir. Ayrıca nehrin Klodnica kolu üzerinde inşa edilen ve rezervuar kapasitesi $94 \mathrm{hm}^{3}$ olan Dzierzno Duze ile Mala Panew kolu üzerinde inşa edilen ve rezervuar kapasitesi 92,61 hm³ olan Turawa, havzada inşa edilen diğer barajlardır (URL 5).

Söz konusu akarsu havzasındaki barajların bulunduğu yerlere dikkat edilirse, bunların tamamının nehrin ana yatağı üzerinde değil de kolları üzerinde inşa edildiği anlaşılmaktadır. Bunun birinci nedeni, taşkınların daha akarsuyun kollarındayken kontrol altına alınmak istenmesidir. İkinci nedeniyse nehrin ana yatağının ulaşım amacıyla kullanılmasıdır. Çünkü Oder Nehri, inşa edilen kanallar aracılığıyla büyük sanayi ve ticaret bölgeleri arasındaki ulaşımı sağlayan önemli bir suyoludur.

Nitekim bu akarsu ağı üzerinde; Oder-Spree, Oder-Havel ve Bydgoszcz gibi kanallar bulunmaktadır. Bunlardan Oder-Spree Kanall, Berlin'de akmakta olan Dahme Nehri ile Oder kıyısında bulunan Eisenhütten şehri arasındaki bağlantıyı sağlamaktadır. Oder-Havel Kanalı ise Oder Nehri üzerindeki Cedynia șehri ile Berlin şehrinin yakınlarından geçen ve aynı zamanda da Elbe Nehri'nin kollarından birisi olan Havel'i birbirine bağlamaktadır. Dolayısıyla her ikisi de Almanya'da bulunan bu kanallar vasıtasıyla Oder'in Batı Avrupa suyolu sistemiyle bağlantısı bulunmaktadır. Ayrıca Polonya'da bulunan Bydgoszcz Kanalı ile de Oder'in, Warta ve Notec kolları üzerinden yine Baltık Denizi'ne dökülen bir diğer nehir olan, Vistül ile bağlantısı sağlanmıştır.

\section{MATERYAL VE YÖNTEM}

Çalışmanın amacı, Orta Avrupa'nın önemli akarsularından birisi olan Oder Nehri Havzası'nda yaşayanları tehdit eden beşeri ve doğal faktörlerin neler olduğunu tespit ederek bunlara ilişkin çözüm önerileri getirmektir.

Araștırmaya önce söz konusu akarsu havzasının konumunu ve sınırlarını gösteren bir haritanın ArcMap10.1 ortamında hazırlanmasıyla bașlanmıștır (Șekil 1). Bundan sonra da yine aynı programla Oder Nehri'ni oluşturan kolları, bu akarsu üzerinde inşa edilen kanal ve barajları gösteren bir fiziki harita hazırlanmıştır (Şekil 2). Bu haritalar vasıtasıyla çalışmaya hem görsellik katılmış ve hem de söz konusu akarsu havzasına ilişkin bilgiler, doğru bir şekilde verilmeye çalışılmıştır.

Ardından literatür taraması yapılarak konuyla ilgili hazırlanan; rapor, makale, kitap, dergi ve diğer kaynaklar temin edilmiştir. Bunlardan Oder Nehri Havzası'nda; hangi ülkenin ne kadar toprağı bulunduğu, bu ülkeler arasında havzayı içine alacak şekilde yaşanılan tarihsel süreç, nehrin kolları, nehrin kolları üzerinde inşa edilen önemli su yapıları ve nehrin hangi amaçlarla kullanıldığı gibi bilgiler saptanmıştır. Daha sonra tüm bu veriler metin analizi yöntemiyle gözden geçirilerek nehir havzasında yaşayanları tehdit eden faktörler ve bunlara ilişkin çözüm önerileri sentez yöntemiyle ortaya konulmuştur.

\section{BULGULAR}

Oder Nehri Havzası'nda yaşayanları tehdit eden beșeri ve doğal faktörleri; sel ve taşkınlar, kirlilik, küresel ısınma ve Polonya ile Almanya arasındaki tarihsel süreç olmak üzere dörde ayırmak mümkündür. 
Havzada yaşayanları tehdit eden faktörlerden ilkine, nehir ve yakın çevresinde zaman zaman meydana gelen, sel ve taşkınları örnek olarak göstermek mümkündür. Yaz mevsiminde Macar Ovası üzerinde oluşan alçak basınç merkezinden gelen sıcak ve nemli hava kütleleri Polonya'ya doğru ilerlerken, Arktik Bölge üzerinden gelen soğuk ve nemli hava kütleleriyle karşılaşmaktadır. Böyle zamanlarda Oder'in yukarı havzasında bulunan (Batı Beskidler, Jesenik ve Snieznik gibi) dağlık alanlara şiddetli yağışlar düşmektedir. Bunlar da, özellikle Oder Nehri'nin kollarıyla birleşme noktalarında, sellere neden olmaktadır. Nitekim Haziran 1902, Temmuz 1903, Ağustos 1977, Ağustos 1985 ve Temmuz 1997'de olmak üzere; XX. yüzyılda bu şekilde havzada 5 büyük sel meydana gelmiştir. Oder Havzası'nda doğal taşkın dalgasının sebep olduğu zararları önlemek amacıyla, sel sularının yönlendirilmesi ve azami deşarjın azaltılmasında rol oynayan, depolama havuzları ve diğer hidro-teknik altyapılar inşa edilmiştir (Dubicki vd., 2005).

Ancak tarım arazilerini ve kırsal yerleşmeleri korumak amacıyla inşa edilen setler, sellerin büyük ölçüde zayıflamasını sağlayan doğal depolama alanlarını elimine etmiştir. Taşkın ovalarının ortadan kaldırılması da taşkından korunmayı olumsuz bir şekilde etkilemiştir. Çünkü su miktarları, inşa edilen acil depolama hacimlerine kıyasla oldukça büyüktür. Nitekim 1997 yılının temmuz ayında meydana gelen büyük selde, yukarıdaki rezervuarlardan bırakılan sular nedeniyle, Oder Nehri üzerindeki kimi yerleşim birimlerindeki taşkın hasarı daha fazla olmuștur (Kowalczak ve Kundzewicz, 2011). Gerçekten de bu sel, Polonya'daki Chalupki ile Slubice ilçeleri arasındaki kesitte 19 gün boyunca etkili olmuştur (Dubicki vd., 2005).

Aşırı yağmurun bir sonucu olarak meydana gelen bu afet, son 200 yılda havzada yaşanan en kötü ve yıkıcı sel olmuştur. Üst ve orta Oder nehir havzası ve üst Vistül nehir havzasındaki yedi ilin \% 25'inden fazlasını sular altında bırakan bu sel, yaklaşık 3 milyar Amerikan Doları zarara da yol açmıştır (Van Gelder vd., 1999). Bu afet yüzünden Çek Cumhuriyeti'nde 48, Polonya'daysa 56 kişi hayatını kaybetmiştir. Bundan başka Polonya'da yaklaşık 650.000 hektar genişliğinde arazi ile 1.362 yerleşim birimi de sular altında kalmış ve buralarda yaşayan 160.000 'den fazla kişi de tahliye edilmiştir (Niesche, 2003).

Söz konusu sel, nehrin Almanya-Polonya sınırını oluşturan aşağı kesimindeyse temmuz ayı ortalarında kabarmaya başlayıp ağustos başına kadar devam etmiştir. Bu afet, Federal Almanya için de bir dönüm noktası olmuştur. Nitekim II. Dünya Savaşı'ndan belirtilen yıla (1997) kadar adeta ordusunu yok sayan Almanya, bu olayı silahlı kuvvetlerini temize çıkarmak ve hatta onunla övünmek için bir fırsat olarak kullanmıştır. Gerçekten de Oder Nehri kıyısındaki Frankfurt kasabası ve birkaç köyün taşkın tehlikesi geçirmesi üzerine Alman hükümeti, afet bölgesine 9 bin asker sevk etmiştir. Bunlar, Oder Nehri kenarını kum torbalarıyla doldurmak başta olmak üzere taşkın zararının azaltılmasında önemli roller oynamıştır. Alman hükümeti de bu tehlikeyi yalnızca ülkenin doğusunun değil, bütün ulusun başına gelmiş bir millî felaket ilân etmiştir. Bu olay, iki Almanya'nın birleşmesinden sonra ülkenin ilk kez birlikte hareket etme deneyimi ve orduyla milletin yeniden buluşması şeklinde lanse edilmiştir (İnce, 1997).

Ayrıca bu selin yol açtığı bir başka sorun da çevre ve canlı sağlığı açısından olmuştur. Nitekim havzada yaşanan bu sel sonrasında polisiklik aromatik hidrokarbon (PAH) kirliliğini tespit etmek amacıyla Oder Nehri ve Szczecin Lagünü'ndenki sedimanlardan örnekler alınmıștır. Bu örneklerde ortalama değerlere kıyasla yüksek PAH seviyeleri tespit edilmiștir. Bunlar, sel sırasında belediye ve endüstriyel tesislerin atık bertaraf alanlarında meydana gelen taşkınlardan kaynaklanmıştır (Witt, Siegel, 2000, 1124). PAH'lar organik bileşiklerin eksik yanması sonucu ortaya çıkan toksik ve kansorejen etkiye sahip yine organik yapıda olan bileşiklerdir. PAH'ların; su, hava ve gıdalar yoluyla vücuda girerek insan DNA'sında mutasyona sebep olduğu bilinmektedir (Alver vd., 2012). 
Oder Nehri'nde yaşayanları tehdit eden faktörlerden ikincisi, kirliliktir. Bundaysa nehir ve kollarının gerek yoğun sanayileşmiş bölgelerden geçmesi ve gerekse ulaşım açısından kullanılması gibi beșeri hususlar etkilidir. Nitekim Oder'in yukarı çı̆̆ırındaki büyük kirletici yükler, nehrin orta ve aşağı mecrasında su tüketicileri ve kullanıcıları için büyük sorunlar yaratmakla kalmamakta, aynı zamanda Baltık Denizi'ni de kirletmektedir. Konuyla ilgili Çek Cumhuriyeti ve Polonya'da bu ülkelerin ekonomilerini önemli ölçüde değiştiren siyasi dönüşümden önceki ve sonraki dönemi (1970-2000 ve 1991-2000) kapsayan bir araştırma yapılmıştır. Buna göre 1990'lı yıllarda birçok endüstri tesisinin kapatılması ve kanalizasyon arıtımının iyileştirilmesinin bir sonucu olarak Oder'deki zayıf su kalitesinin önemli ölçüde iyileştiği görülmüştür. Bununla birlikte, tuzlu maden suları ile yüzey erozyonu sonucunda nehirlerde ve rezervuar tabanlarında tortulaşmayla birçok tehlikeli maddenin uzun süredir birikmesi de halen havzada çözülmeyi bekleyen problemler arasındadır (Absalon ve Matysik, 2007).

Yine bu konuyla ilgili olarak akarsuyun orta mecrasında yapılan bir çalışma Oder'in; kadmiyum, çinko, bakır ve nikel konsantrasyonları açısından ciddi oranda kirlendiğini ortaya koymuştur. Özellikle Polonya'nın Lubin kasabası ile Legnica şehri arasında kalan sahada bakır madenciliği sebebiyle yüksek seviyede; kadmiyum, bakır ve çinko konsantrasyonları tespit edilmiştir. Bu metallerden kadmiyum, nehir boyunca suyun yüksek seviyelerde akması nedeniyle özel bir endişe kaynağı olarak görülmektedir (Adamiec ve Helios-Rybicka, 2002).

Nehrin aşağı havzasında yer alan Dabie Gölü'nde yapılan başka bir araştırmaysa göl sularının; krom ve cıva konsantrasyonu açısından sınır değerlerin çok üzerinde; kurşun ve çinko konsantrasyonu açısından da uygun görülen sınır değerlerin üzerinde bir durum sergilediğini ortaya koymuştur. Ayrıca nikel ihtivası bakımından da göl sularının kritik değerlere çok yakın olduğu tespit edilmiştir (Daniszewski, 2014).

Oder Nehri Havzası'nda yaşayanları tehdit eden ve gelecekte daha da etkili olması beklenen faktörlerden üçüncüsü, küresel ısınmadır. Nitekim iklim değişikliğinin Oder'in haliç bölgesindeki muhtemel etkileri üzerine yapılan bir çalışma, sahada kuraklığın gittikçe artacağını ortaya koymuştur. Buna göre yaz aylarında azalan yağışlara bağlı olarak Oder Nehri'nin besleyici yüklerinin azalacağı ve sıcaklık artışına bağlı olarak haliç çevresindeki su kalitesinde birtakım değişimlerin meydana geleceği öngörülmektedir (Janßen, 2007).

Ayrıca küresel ısınma nedeniyle dünya genelinde olduğu gibi Baltık kıyılarında da deniz seviyesinde yükselmeler meydana gelmektedir. Ancak yapılan araştırmalar, günümüzde bu denizin seviyesinde yaşanan değişimlerde küresel ısınmadan ziyade İskandinav Plakası'nın hareketlerinin etkili olduğunu göstermiştir. Nitekim buna bağlı olarak Baltık Denizi'nin GD'sinde hesaplanan ortalama yükselme, yılda 1,7 mm'dir. Yine yapılan araştırmalar küresel ısınma yüzünden eriyen buzulların Baltık'taki ortalama tuzluluk derecesini daha da azaltacağını ve bunun da deniz ekosisteminde büyük değişikliklere yol açacağını ortaya koymuştur. Gerçekten de bu denizde; yaşamlarını buzul örtüsüne bağlı olarak devam ettiren fok gibi deniz memelilerinin sayıca azalması, su sıcaklığındaki yükselmeye bağlı olarak yeni türlerin hâkim duruma gelmesi, genel olarak türlerin hem bileşiminde ve hem de dağılışında belirsizliklerin oluşması beklenmektedir (HELCOM, 2007).

Bununla birlikte iklim değişikliğinin Oder Halici çevresini tamamen olumsuz bir şekilde etkileyeceğini söylemek de doğru değildir. Nitekim bilim çevrelerinde, küresel ısınmanın turizm açısından belirtilen sahayı olumlu yönde etkileyeceği beklentisi hâkimdir. Çünkü genel itibarıyla daha sıcak ve süresi uzamış bir yaz mevsiminin turistler açısından cazip olduğu bilinen bir gerçektir (Janßen, 2007). 
Havzada yaşayanları tehdit etme potansiyeli bulunan konulardan bir diğeri de Polonya ile Almanya arasında yaşanan tarihsel süreçtir. Sorunun daha iyi anlaşılması açısından iki ülke arasında geçmişten günümüze kadar neler yaşandığına kısaca değinmek yerinde olacaktır:

IX. ve X. yüzyılda Polonya devleti, Oder ve Vistül nehirleri arasında gelişmiştir. Ancak XII-XIII. yüzyılda meydana gelen Alman geniş̧lemesi sırasında Polonyalılar, Oder Nehri civarındaki topraklardan doğuya doğru çekilmek zorunda kalmıştır (URL 3). Bu durum aşağı yukarı I. Dünya Savaşı'na kadar devam etmiştir.

Almanya'nın I. Dünya Savaşı'nda ağır bir yenilgi alması üzerine İtilaf Devletleri'yle bu ülke arasında 1919 yılında Versay Antlaşması'nı imzalanmıştır. Buna göre Almanya; Yukarı Silezya'nın güney ucu ve Batı Prusya'nın büyük bölümünü Polonya'ya bırakmıștır. Ayrıca XII. yüzyıldan beri Polonya ile arasında ihtilafa konu olan ve nüfusunun \% 95'i Alman asıllı olmasına rağmen, Danzig'e (bugün Polonya'ya bağlı büyük şehirlerinden birisi olan Gdansk) serbest şehir statüsünün verilmesini ve onu Milletler Cemiyeti'nin himayesine bırakmayı da kabul etmiştir (Minahan, 2000).

Yine aynı anlaşmaya göre Opava ile birleşmesinden itibaren Oder'in uluslararası bir akarsu olduğu ilan edilmiștir. Buna göre belirtilen kısımdan itibaren Oder'in deniz erişimi sağlayan tüm gezilebilir kısımlarının idaresinin; Polonya, Çekoslovakya, İngiltere, Fransa, Danimarka ve İsveç'ten birer, Prusya'dansa 3 temsilcinin olduğu uluslararası bir komisyona devredilmesi kabul edilmiştir (Bevans, 1968).

Ancak Uluslararası Oder Komisyonunun faaliyete geçmesinin ardından Polonya delegesi, onun yargılama yetkisinin Warta ve Notec'in ülkesinin topraklarında kalan bölümlerini kapsamadığını beyan etmiştir. Bu yüzden ortaya çıkan anlaşmazlık, komisyonda tıkanmaya sebep olmuş ve konunun çözümü için Uluslararası Adalet Divanı'na başvurulmuştur. Mahkeme 10 Eylül 1929 tarihinde açıkladığı kararında Versay Antlaşması'nın 331. maddesinde yer alan “doğal olarak veya kanallar aracılığıyla yönlendirilebilen ya da yönlendirilebileceği noktalara kadar uzanan veya aynı nehrin doğal olarak gezilebilen iki bölümünü birleștiren" hükmü uyarınca, Uluslararası Oder Komisyonu'nun yetkisinin, akarsuyun gezilebilir tüm kısımlarını kapsadığını belirtmiştir (URL 1). Böylece komisyonun çalışmasında tıkanmaya sebep olan sorun, Uluslararası Adalet Divanı'nın katkısıyla çözülmüştür.

Versay Antlaşması'nda topraklarının büyük bir kısmını kaybeden ve çok ağır şartlara imza atmak zorunda bırakılan Almanların kırılan onurunu çok iyi kullanan Hitler, 1929 yılında ortaya çıkan Dünya Ekonomik Buhranı'ndan da yararlanarak halka vadettiği umutlarla ülkenin başına geçmiştir. Hitler önderliğinde Almanya, kısa süre içerisinde toparlanarak ekonomik ve askeri açıdan büyük bir güç haline gelmiştir. Bundan sonra Hitler, Almanya'nın Versay'ın zincirlerinden kurtarılması planını uygulamaya koymuştur. Bu kapsamda Almanya, 14 Kasım 1936 da, Versay Antlaşması ile enternasyonalize edilen Alman nehirlerine ait Versay hükümlerini ilga ederek bu su yolları üzerindeki mutlak egemenliğini tekrar kurmuştur. Nitekim bundan Oder Nehri de etkilenmiştir. Bunu ülke sınırları dışında yaşayan bütün Almanların tek bir devlet çatısı altında toplanması ve dahası Almanların yaşamadığ birçok memleketi de kendi sınırları içine katma planının uygulamaya konması takip etmiştir (Armaoğlu, 1999).

SSCB ile saldırmazlık paktı imzaladıktan sonra Polonya üzerindeki baskıyı artıran Almanya; 2930 Ağustos 1939'da Danzig serbest şehrinin kendisine verilmesini, koridor bölgesi için plebisit yapılmasını, seferberliğin kaldırılmasını ve bu konuların görüşülmesi için bir Polonya temsilcisinin 30 Ağustos günü Berlin'de hazır bulunmasını istemiştir. Polonya, bu istekleri kabul etmiş fakat belirtilen tarihte temsilcisini Berlin'e göndermemiştir. Bunun üzerine Almanya, 1 Eylül 1939'da Polonya'yı işgale başlamıştır. İngiltere ve Fransa, Almanya'dan istilâyı sona erdirerek 
birliklerini Polonya'dan çekmesini istemiştir. Ancak buna olumlu bir yanıt gelmeyince onlar da 3 Eylül 1939'da Almanya'ya savaş ilan etmişlerdir. Böylece 6 yıl sürecek olan II. Dünya Savaşı başlamıștır. Almanya, Sovyet Sosyalist Cumhuriyetler Birliği (SSCB) ile yaptığı anlaşma gereğince Varşova dâhil Polonya'nın batısını, Sovyetler de bu ülkenin doğusunu işgal etmiştir (Yakut, 2013).

Ancak daha sonra Hitler'in SSCB ile yaptığı saldırmazlık anlaşmasını rafa kaldırıp bu ülkeye de savaş ilan etmesi ve Amerika Birleşik Devletleri (ABD)'nin de savaşa müdahil olmasıyla dengeler değişmiştir (Erhan, 1996). Böylece Almanlar, savaştaki üstünlüklerini kaybetmeye başlamışlardır.

1945 yılı başında Vistül-Oder adı verilen askeri bir harekâtla Kızıl Ordu, Vistül ve Oder nehirleri üzerinden Berlin'e doğru ilerlemiştir (Sırakaya, 2007). Ve nihayet 8 Mayıs 1945 tarihinde Almanya'nın teslim olmasıyla Avrupa'da II. Dünya Savaşı sona ermiştir (Jahn, 2015).

Nüfus ve etnik yapı açısından özellikle 1939-1949 yılları arasında Polonya; ölümler, göçler ve yaşanan savaşın politik sonuçları nedeniyle büyük bir değişime uğramıştır. Nitekim 1939 yılında 35 milyon olan Polonya nüfusu, 1946 yılına gelindiğinde 26 milyona kadar gerilemiştir (Akkan, 2007). Savaşın sebep olduğu diğer yıkımlar bir yana sadece bu harpte 4,3 milyon ölen sayısıyla Polonya, SSCB'den sonra en fazla insan kaybeden ülke olmuștur (Mee, 1984).

Bütün bunlar dikkate alınarak SSCB, ABD ve İngiltere arasında 1945 yılında yapılan Potsdam Toplantısı'nda Almanya-Polonya sınırının Oder-Neisse hattından Baltık Denizi'ne kadar uzanması kararlaştırılmıştır. Buna bağlı olarak nehrin doğusunda kalan Almanların da bu topraklardan göç ettirilmesine ve onlardan boşalan yerlere Polonya vatandaşlarının yerleştirilmesine karar verilmiştir. Bu şekilde belirtilen sahada iskân edilen Polonyalıların sayısı, 8 milyondan fazladır (Staar, 1984). Böylece Almanya, XII. yüzyıldan itibaren Polonya ile arasında ihtilafa konu olan sahayı savaş tazminatı olarak bu ülkeye tekrar bırakmak zorunda kalmıştır.

Yaşanan iki dünya harbinde yenilgiye uğrasa da bu savaşlarda oynadığı roller nedeniyle Almanya, diğer Avrupa halklarının bilinçaltında, ister istemez korku duyulan bir ülke olmuştur. Bu nedenle diğer Avrupa devletleri, kontrol altında tutabilmek maksadıyla, bu ülkeyi Kuzey Atlantik Antlaşması Örgütü (NATO) ve Avrupa Ekonomik Topluluğu'na (AET) kabul etmiştir. Ancak 1991 yılında Soğuk Savaş'ın sona erip iki Almanya'nın birleşmesi üzerine AET ülkeleri, Federal Almanya'nın birlikten ayrılma ihtimali konusunda, telaşa düşmüştür. Böylece yeniden yapılandırılarak Avrupa Birliği (AB) adını alan birliğe, Orta ve Doğu Avrupa'dan da çok sayıda yoksul ülke üye olarak kabul edilmiştir. Bununla sözü edilen devletlerin birlikten kopacak Federal Almanya'nın değil, AB'nin kontrolü altında tutulması amaçlanmıştır (URL 6).

Dünya ekonomisinin son yüzyılda yaşadığı en büyük bunalımlardan birisi olan 2008 Küresel Finans Krizi'nden en çok etkilenen yerlerden biri de AB olmuştur. 2008 ve 2009 yllında bu krizin etkileri ile mücadele eden Avrupa, 2010 yılında Yunanistan'da başlayan ve domino etkisi ile diğer $\mathrm{AB}$ ülkelerine de sıçrayan ikinci bir dalga borç kriziyle karşı karşıya kalmıştır. Bu krizde AB'nin istikrarına ilişkin aldığı kararlar ve yönlendirici pozisyonu nedeniyle "Acaba Almanya, bölgesel bir hegemonik güç mü oluyor?” şeklinde bazı sorular gündeme gelmiştir (Vatandaş, 2014).

Almanya'nın güçlü bir imparatorluğa dönüşmesinde büyük bir rol oynayan ve aynı zamanda ilk şansölyesi olan Otto von Bismarck, 30 Eylül 1862 tarihinde yaptığı meşhur konuşmasında, "Zamanın büyük sorunları, konuşmalar ve çoğunluk kararlarıyla değil, demir ve kanla çözülecek." demişti (URL 7). Bu düşünce, yukarıda da değinildiği üzere, XX. yüzyılda iki dünya savaşının çıkmasına sebep olmuştur. Ancak bu savaşlarda yapamadıklarını Almanlar, nihayet AB çatısı altında güçlü ekonomileriyle başarmış gibi görünmektedir (URL 8). Ve bu durum sözü edilen devletin bulunduğu kıtanın kontrolünü gittikçe ele geçirdiğini anlatmak için kimi çevrelerce, 
"Dördüncü Reich" yani Almanların tarihte kurduğu IV. İmparatorluk olarak da nitelendirilmesine yol açmıştır (URL 9).

Bugünün Almanya'sında başarılı bir demokrasi olduğu düşünüldüğünde böyle bir nitelendirme saçma gibi gelebilir. Ancak onun tamamen yersiz olduğunu söylemek de mümkün değildir (URL 10). Dolayısıyla zayıf da olsa gelecekte eğer böyle bir durum gerçekleşirse muhtemelen bundan Oder Havzası'nda yaşayanlar da etkilenecektir.

\section{TARTIŞMA VE SONUÇ}

Orta Avrupa'nın önemli akarsularından birisi olan Oder Nehri Havzası'nda yaşayanları tehdit eden beșeri ve doğal faktörlerin neler olduğunu ortaya koymak amacıyla hazırlanan bu çalışmadan elde edilen sonuçlar ve bunlara ilişkin çözüm önerileri şunlardır:

Havzada yaşayanları tehdit eden unsurlardan ilki, nehir ve yakın çevresinde zaman zaman meydana gelen, sel ve taşkınlardır. Bu afetleri önlemek maksadıyla nehrin kolları üzerinde depolama havuzları inşa edilmiştir. Ancak bu yapıların hacimleri, büyük sellerle gelen suları depolayacak kapasitede olmadığı için, sel ve taşkından korunma ihtiyacını yeterince karşılayamamaktadır. Dahası meydana gelen büyük sellerde nehrin yukarı havzasındaki rezervuarlardan büyük miktarlarda su bırakılmakta ve bu da taşkınların sebep olduğu zararları daha da artırmaktadır (Kowalczak ve Kundzewicz, 2011).

Sel ve taşkın zararlarının önlenmesi için su havzalarının planlaması ve yönetilmesi oldukça önemlidir (Yüksel vd., 2013). Taşkınların yaratabileceği olumsuz etkileri azaltmak için de öncelikle havza bazında yönetimi esas alan taşkın tehlike risk haritaları ile taşkın riski yönetim planlarının hazırlanması gerekmektedir (European Commission, 2007). Bundan sonra da taşkın koruma yapılarına daha çok nerelerde ihtiyaç duyulduğu belirlenerek oralara bent, baraj veya göletler inşa edilmelidir. Ayrıca taşkın tekerrür debileri dikkate alınarak riskli yerleşim alanlarında yaşayanları koruyacak tedbirler de alınmalıdır (Kerim ve Süme, 2019).

Oder Havzası'nda yaşayanları tehdit eden faktörlerden ikincisi, kirliliktir. Bundaysa nehir ve kollarının gerek yoğun sanayileşmiş şehirlerden ve gerekse maden sahalarından geçmesi etkilidir (Adamiec ve Helios-Rybicka, 2002). Suyun temel ekolojik destek işlevlerinin korunması, sağlıklı ve sürdürülebilir bir kalkınma açısından mutlaka gereklidir. Su kaynaklarının sürdürülebilir yönetiminde kirliliğin önlenmesi için "kirleten öder" ilkesi gereğince sadece arıtma teknolojilerini temel alan çözümler, bütünsel yaklaşım olmadan yetersiz kalmaktadır. Bunun için coğrafi bilgi sistemleri (CBS) kullanılarak akarsu kirlilik verilerinin toplanması, sayısal ortamda depolanması, konumsal analizlere olanak sağlayacak şekilde sorgulanması ve bunların zararlarını ortadan kaldırmak için gerekli takibin yapılması zorunludur (Gümrükçüoğlu ve Baştürk, 2008).

Havzada yaşayanları tehdit edebilecek bir diğer faktör de küresel ısınmadır. Nitekim iklim değişikliğine bağlı olarak havzada bir yandan yaz aylarında yağıșlar azalırken öte yandan kuraklığın daha da artması beklenmektedir. Bunun sonucunda da Oder'in taşıdığı su miktarında meydana gelecek azalmaya bağlı olarak hem nehirde taşınan besleyici yüklerin azalacağı, hem de Oder'in haliç bölgesindeki su kalitesinde birtakım değişimlerin olacağı öngörülmektedir (Janßen, 2007).

Oder Nehri Havzası'nda küresel ısınmanın sebep olacağı su ve gıda güvenliği tehdidine karşı önlem olarak da bent, baraj veya göletler inşa edilebilir. Ancak bu yapılırken de çevreye ve iklime en az zarar verecek nitelikte projelere odaklanılmalıdır. Bu maksatla inşa edilecek su yapıları, aynı zamanda havzadaki sel ve taşkın zararlarının önlenmesine de katkı sağlayacaktır. 
Havzada yaşayanların su güvenliğini sağlamak adına alınabilecek bir başka önlem de kuraklığın etkili olabileceği şehirlerde, suyun tekrar kullanımını sağlayacak modern ve ekolojik arıtma sistemlerinin kurulması olabilir. Alınacak böyle bir önlem, aynı zamanda havzada yaşayanları tehdit eden faktörlerden ikincisi olan, su kirliliği sorununun çözümüne de katkı sağlayacaktır.

Ayrıca küresel ısınma ve iklimde değişikliklere yol açan sera gazlarının salınımının önlenmesi için; ağaçlandırma, karbon için bir fiyat getirme ve enerji üretiminde fosil yakıtların yerine yenilenebilir enerji kaynaklarına yönelme gibi bir takım ilave önlemler, havza ülkelerinin tamamında da alınabilir (URL 11).

Oder Nehri Havzası'nda yaşayanları tehdit edebilecek unsurlardan bir diğeri de, günümüzde AB'nin lokomotifi olarak kabul edilen, Almanya'nın iktisadi gücünün giderek siyasi güce dönüşmesidir. Nitekim geçmiște yaşanan iki dünya savaşından yenik çıkan Almanya, bu harplerde asırlardır aralarında ihtilafa konu olan ve Oder Havzası'nı da içine alan toprakları Polonya'ya bırakmak zorunda kalmıștır. Ve bu da gelecekte her iki ülke arasında tekrar sorun yaşanmasına sebep olabilir.

Ancak, geçmişte yaşanan büyük ve kanlı savaşlardan alınan dersler sonrasında kurulup genişleyen ve kıtaya hem barışın hem de refahın gelmesinde büyük katkıları olan, Avrupa Birliği çatısı altındaki bu iki ülke arasında şuan için böyle bir sorun yaşanma olasılığı çok zayıf görünmektedir.

\section{KAYNAKLAR}

Absalon, D., Matysik, M. (2007). Changes in water quality and runoff in the Upper Oder River Basin. Geomorphology, 92(3-4), 106-118.

Adamiec, E., Helios-Rybicka, E. (2002). Distribution of Pollutants in the Odra River System Part IV. Heavy Metal Distribution in Water of the Upper and Middle Odra River, 1998-2000. Polish Journal of Environmental Studies, 11(6), 669-673.

Akkan, E. (2007). Polonya. İslâm Ansiklopedisi. 34, 307-309. İstanbul: TDV Yayınları.

Alver, E., Demirci, A., Özcimder, M. (2012). Polisiklik Aromatik Hidrokarbonlar ve Sağlığa Etkileri. Mehmet Akif Ersoy Üniversitesi Fen Bilimleri Enstitüsü Dergisi 3 (1), 45-52.

Armaoğlu, F. (1999). 20. Yüzyıl Siyasi Tarihi (Cilt 1-2: 1914-1995). İstanbul: Alkım Yayınevi.

Baran, T., Öziş, Ü., Özdemir, Y. (2006). “Sınır Aşan Asi Havzası Su Potansiyeli ve Yararlanılması”, TMMOB Su Politikaları Kongresi Bildiriler Kitabı. 2, 571-581. Ankara: İnşaat Mühendisleri Odası.

Bevans, C. I., (1968). Treaties and Other International Agreements of the United States of America, 1776 1949: Multilateral, 1918-1930, Department of State.

Bilen, Ö. (2009). Türkiye'nin Su Gündemi: Su Yönetimi ve AB Su Politikaları. Ankara: DSi̇.

Daniszewski, P. (2014). Heavy metals in the waters of Dąbie Lake (West-Pomeranian Voievodship, NorthWest Poland) in the years 2008-2012. International Journal of Chemical and Biochemical Research, 4, 72 81.

Doğanay, H. (1997). Türkiye Beşeri Coğrafyası. İstanbul: MEB Yayınları No: 2.982, Bilim ve Kültür Eserleri Dizisi: 877, Eğitim Dizisi: 10. 
Dubicki, A., Malinowska-Małek, J., Strońska, K. (2005). Flood hazards in the upper and middle Odra River basin - A short review over the last century, Limnologica - Ecology and Management of Inland Waters, 35(3), 123-131.

Dysarz, T., Wicher-Dysarz, J., Przedwojski, B. (2006). Man-Induced Morphological Processes In Warta River (Poland), And Their Impact On The Evolution Of Hydrological Conditions. River Flow, 2, 1301-1310.

Erhan, Ç. (1996). Avrupa'nın İntiharı ve İkinci Dünya Savaşı Sonrasında Temel Sorunlar. Ankara Üniversitesi Siyasal Bilgiler Fakültesi Dergisi, 51(1), 259-273.

European Commission. (2007). Directive 2007/60/EC of the European Parliament and of the Council of 23 October 2007 on the assessment and management of flood risks. Official Journal of the European Union, 15(1), 27-34.

Giordano, M. and Wolf, A. T. (2003). Sharing Waters: Post-Rio İnternational Transboundary Water Management. Natural Resources Forum, 27(2), 163-171.

Gümrükçüoğlu, M. ve Baştürk, O. (2008, Mart). Sürdürülebilir Su Yönetiminde Nehir Kirliliği Üzerine Bir Çalışma, TMMOB 2. Su Politikaları Kongresi, Ankara.

HELCOM. (2007). Climate Change in the Baltic Sea Area. Helsinki: Baltic Sea Environment Proceedings No: 111.

İnce, S. (1997). Almanya: Devlet Küçülüyor, Ordu Büyüyor. Birikim, 101, 6-10.

Jahn, E. (2015). German Domestic and Foreign Policy: Political Issues Under Debate (Volume: 2). Frankfurt/Main: Springer.

Janßen, H. (2007). Climate Change in the Oder/Odra Estuary Region, G. Schernewski et al. (Ed): Coastal Development: The Oder Estuary And Beyond. Rostock: EUCC, Coastline Reports: 8, 1-10.

Kerim, A., Süme, V. (2019). Taşkınlar, Taşkın Koruma ve Kontrol Yapıları; Rize İlinde Örnek Çalışmalar. Türk Hidrolik Dergisi, 3(1), 1-13.

Kowalczak, P., Kundzewicz, Z. W. (2011). Water-related conflicts in urban areas in Poland. Hydrological Sciences Journal, 56(4), 588-596.

Köle, M. M. (2017). 1954-2016 Dönemi Türkiye Sınıraşan Sular Politikası. Marmara Coğrafya Dergisi, (35), 122-133.

KZGW (Krajowy Zarząd Gospodarki Wodnej). (2014). Projekt aktualizacji Planu gospodarowania wodami na obszarze dorzecza Odry. Warszawa: Krajowy Zarząd Gospodarki Wodnej.

Maden, T. E. (2013). Sınıraşan Su Havzalarında İşbirliği Sorunu. Ortadoğu Analiz, 5(53), 23-31.

Mee, C. L. The Marshall Plan: The Launching of the Pax Americana. New York: Simon and Schuster.

Minahan, J. (2000). One Europe, Many Nations: A Historical Dictionary of European National Groups. London: Greenwood Publishing Group.

Moore, S. (2016). The Fourth Reich?: The EU - An Emerging German Empire. Jollies Publishing.

Niesche, H. (2003). The Oder River Flood in Summer 1997 from Brandenburg's Point of View. In: Zschau J., Küppers A. (eds) Early Warning Systems for Natural Disaster Reduction. Springer, Berlin, Heidelberg, 289303. 
Sırakaya, S. (2007). İkinci Dünya Savașı ve Azerbaycan. (Yayınlanmamış Yüksek Lisans Tezi), Ankara Üniversitesi Sosyal Bilimler Enstitüsü, Ankara.

Staar, R. F. (1984). Communist Regimes in Eastern Europe. California: Hoover Instution Press.

Uitto, J. (2001). Global Freshwater Resources. Societies and Environments, 3, 65-76.

URL 1, https://www.internationalwaterlaw.org/cases/river-oder.html, (Son Erişim: 28.01.2020)

URL 2, https://www.unece.org/fileadmin/DAM/env/teia/doc/Slubice_09/14AndreasMuehlberg-EN.pdf, (Son Erişim: 28.01.2020)

URL 3, https://www.britannica.com/place/Oder-River, (Son Erişim: 28.01.2020)

URL 4, http://www.mkoo.pl/index.php?mid=2\&lang=EN, (Son Erişim: 28.01.2020)

URL 5, http://www.pogodynka.pl/hydro/biuletyncodzienny, (Son Erişim: 28.01.2020)

URL 6, http://soyledik.com/tr/analiz/409/yeni-bir-alman-sorunu-ve-fransa--dr-dilek-yigit.html, (Son Erişim: 28.01.2020)

URL 7, https://www.thenewamerican.com/culture/history/item/13040-bismarcks-blood-and-ironspeech-150-years-later, (Son Erişim: 28.01.2020)

URL 8, http://www.tarafsizhaber.com/makale/dr-mehmet-hakan-saglam-bismarck-in-almanimparatorlugu-hitler-in-almanyasi-merkel-in-avrupa-birligi-13701, (Son Erişim: 28.01.2020)

URL 9, https://www.telegraph.co.uk/news/2016/05/15/the-fourth-reich-is-here---without-a-shot-beingfired/, (Son Erişim: 28.01.2020)

URL 10, https://www.spiegel.de/international/germany/german-power-in-the-age-of-the-euro-crisis-a1024714.html, (Son Erişim: 28.01.2020)

URL 11, https://www.statista.com/statistics/271748/the-largest-emitters-of-co2-in-the-world/, (Son Erişim: 20.04.2020)

Van Gelder, P. H. A. J. M., Van Noortwijk, J. M., Duits, M. T. (1999). Selection of probability distributions with a case study on extreme Oder river discharges. In Safety and Reliability, Proceedings of ESREL '99-The Tenth European Conference on Safety and Reliability, Munich-Garching, 1475-1480.

Vatandaş, S. (2014). Avro Krizi Sonrası Almanya'nın Tutum ve Konumu. BİLGESAM, 5005, 1-7.

Witt, G., Siegel, H. (2000). The consequences of the Oder flood in 1997 on the distribution of polycyclic aromatic hydrocarbons (PAHs) in the Oder River estuary. Marine Pollution Bulletin, 40(12), 1124-1131.

Yakut, K. (2013). İkinci Dünya Savaşı. İ. Güneş ve C. Bilim (Ed.), Çağdaş Dünya Tarihi. Eskişehir: Anadolu Üniversitesi Yayınları No: 1078, Açıköğretim Fakültesi Yayınları No: 596.

Yüksel, Ö., Serencam, U., Üçüncü, O., Anılan, T. (2013, Ekim). Afet ve Taşkın Yöntemi ve Değirmendere Örneği. Taşkın ve Heyelan Sempozyumu Bildiriler Kitabı. Trabzon. 